\title{
Practice of Real Estate Business in Bangladesh: Prospects \& Problems of High-rise building
}

\author{
${ }^{1}$ Shakila Zerin Bony, ${ }^{2}$ Syka Rahman \\ ${ }^{I}$ Senior Lecturer, Department of Business Administration, Stamford University Bangladesh. \\ ${ }^{2}$ Lecturer,Department of Business Administration,Stamford University Bangladesh.
}

\begin{abstract}
Real Estate Business provides the means of serving one of the basic needs of human being living in the city- the need for shelter or house. The current trend of urban growth in Bangladesh is about 5-6 percent per annum (REHAB, 2013). This will change and increase the demand of people geometrically. At present 28 percent people live in urban areas which are expecting to be 34 percent in 2025 (The Daily Ittefaq, May, 2013). The present estimated population of Dhaka city is 15.93 million and estimated growth rate is 4.7 percent per annum (REHAB, 2013). All these people need shelter. To satisfy the housing need of this huge explosive population, here comes the need of real estate sector. The main focus of this research is the present scenario of real estate business in Bangladesh. This paper also highlights prospects and some problems of high-rise building. The study is descriptive in nature and data were gathered through primary and secondary sources. The result of this study show how real estate business are playing very important role to provide housing facilities regardless of high, middle and low-income people since the past two decades and also creates job opportunities for the unemployed people in Bangladesh and provided remarkable contribution to boost up overall economic conditions of Bangladesh.
\end{abstract}

Keywords: Real Estate business, Bangladesh, building, urbanization, apartment.

\section{Introduction}

Real estate or immovable property is a legal term (in some jurisdictions) that encompasses land along with anything permanently affixed to the land, such as buildings. Real estate is often considered synonymous with real property (also sometimes called reality), in contrast with personal property (also called personality). However, in technical terms, real estate refers to the land and fixtures themselves and real property are used primarily in over real estate. The term real estate and real property are used primarily in common law, while civil law jurisdiction refers instead to immovable property. In law, the word real means relating to a thing as distinguished from a person. Thus the law broadly distinguishes between real property (land and anything affixed to it) and personal property (everything else e.g. clothing, furniture, money). Urbanization is an outcome of both population growth and rural-urban migration. As urbanization increases, more and more people are becoming city dwellers. Bangladesh is not any exception to that picture. In Bangladesh, the problem is further aggravated in urban areas by limited supply of land, ineffective utilization of land, and lack of proper planning regarding construction of buildings to meet the demands of people. The continuous increasing growth of population in urban area is creating and be increasing demand for shelter. According to The Daily Star, November, 20012, "The housing shortage is so acute that one third of the city's population lives in slums". In Bangladesh, the government always tries to solve the housing problem in the cities especially in Dhaka city. It has already been impossible for the government alone to ensure housing facilities for all people in the cities. That is why government and real estate companies in Bangladesh are working hand in hand to meet the everincreasing thirst of people for shelter in the cities. This paper tries to highlight current scenario of real estate in Bangladesh and also problems and prospects of high-rise building.

\section{Literature review}

The term real in real estate comes from the term realty which has for centuries, meant land and all things permanently attached (Fisher, 2000). In a country real estate business can achieve remarkable growth and can ample opportunity to grow further because the land and housing demand of people living in the city are increasing day by day (Michael, 1999). That means the housing is not only provides physical shelter but also have significant impact on the lives of the dwellers in the term of skills enhance, meant, income generation, increased security, health, self confidence \& human dignity. (Hossain, 2001) observed that Bangladesh like many other developing countries face acute shortage of affordable housing both in the urban and rural area.

Since 1985 this sector has created homes for over 20,000 families in the Dhaka Mega City (Seraj, 2003). The lack of available and accessible house has been identified by the government of Bangladesh as one of the important hurdles in improving the housing conditions for middle and lower income household (Hock-smit, 1998). The author also argued although several sources of housing financial for mid and high income customer 
exist, most of the low income families needs are unmet. The housing shortage are estimated in 1991 to be 3.10 million units out of which 2015 million units in rural areas and 0.95 million units in urban areas. The shortage was estimated to be 5.0 million by the end of the year 2009 (National Housing Authority, 2004).

Nordberg (2000) has clearly demonstrated that in most regions, housing has the potential of becoming an engine of economic growth because of its high yield on invested resources, a high multiplier effect, and a host of beneficial forward and backward linkages in the economy. The National Housing Policy (NHP, 1993) commits the government to take initiatives in housing as a provider, for weaker section of the people and as a facilitator in all housing initiatives in Bangladesh.

In Bangladesh low \& middle income people try to land \& build house for their own uses. But (Nadler,2006) argued that still the availability of housing finance is crucial for overall economic development as well as a household welfare \& quality of life.(Malpezzi,2000) observed that the rapid growth of city population has lead to phenomenal increase in housing demand in the city. A new type of residential development has come on the sense which can be broadly termed as apartment (David 2005).

The Eastern housing Ltd. is the pioneer in this sector (Rahman, 2005).This author also said that this housing company had change overall scenario of real estate business in Bangladesh by building more residential apartment as well as commercial housing also The apartment owning is becoming increasingly popular because of economic due to increased land cost as well as construction cost. (Benjamin.D Jone, 2003) argued that reluctance of individual to spend time \& energy in house construction, increase awareness of apartment living. The city itself benefits from the construction of business space \& business activity that apartment development generates. From the aforesaid literature review, it is evident that real estate business one of the fastest growing industrial sectors of Bangladesh. People will need more house, working places, educational institutes and medical centers etc.

\section{Objectives}

The paper aims to examine the present scenario of real estate in Bangladesh. In this broad framework an attempt has been made to achieve the following specific objectives:

i) To discuss about the development of real estate in Bangladesh.

ii) To highlight the prospects of high-rise building.

iii) To find out some problems of high-rise building.

\section{Methodology}

This paper has been prepared relying on primary and secondary information. Primary information has been obtained through a face-to-face interview. Interview was conducted with the concerned personnel to the respective organizations with the help of a structured interview schedule. Sources of pertinent secondary information included the various articles, different books, newspapers and website of the various real estate companies. The secondary information is also collected from Bangladesh Bureau of Statistics \& different Real Estate Company. Tools used for statistical analysis and other data processing was Adobe Illustrator and for tabular and chart was Microsoft Word \& Excel package. The study didn't use any sort of correlation and regression analysis as this study mainly based on qualitative nature.

\section{Limitations}

As it's an ongoing and project based process so it was quite difficult to capture all the areas.

- There are confidential issues like as an employee of marketing it was not possible about investment or fund.

- Organizational policy of not disclosing some data and information for obvious reason.

- Most of the study was dependent on websites. Lack of proper data maintenance was an issue.

\section{Findings and discussion}

\subsection{Overview of Real Estate in Bangladesh}

In Bangladesh, real estate is a recent phenomenon, although such activities started sometime in 1970s. During 1970s there were fewer than five companies in Bangladesh engaged in this business. But in early 1980s with the inception of Eastern Housing Ltd., the apartment project started flourishing. Now this is a booming sector of the economy. Since late 1980s, it came within the preview of business field. As a fast growing city of Bangladesh, such business was initially concentrated in Dhaka. In 1988, there were 42 such developers working in Dhaka and in 2013 there were about 1200 companies engaged in this business (REHAB, 2013). Such activities were later on spread to Chittagong and Khulna cities. At present, there are about 600 firms operating apartment business and they have apartment projects in Dhaka city as well as in some other cities. Over the last 15 years, the real estate development sector has been made significant contribution to our economy. Additionally, thousand of acres of land have been developed into housing estates where upper, lower and middle-income families can construct their own dwellings. The Dhaka Metropolitan city has seen a new 
dimension of modern shopping complex due to the initiative of the Real Estate companies. Private developers construct high-rise apartment buildings with vertical expansion, which requires small size of land for large number of people. Besides, private developers develop buildings in the most planned way that improves the decency. Here we can see different use of Real estate property in Bangladesh from the following:

Table-1 Uses of Civic Amenities

\begin{tabular}{|c|c|}
\hline Uses types & Number \\
\hline Residential & $42 \%$ \\
\hline Commercial & $31 \%$ \\
\hline Residential cum Commercial & $19 \%$ \\
\hline Commercial cum Residential & $8 \%$ \\
\hline Total & $100 \%$ \\
\hline
\end{tabular}

\section{Source: REHAB Directory 2013, REHAB Secretariat}

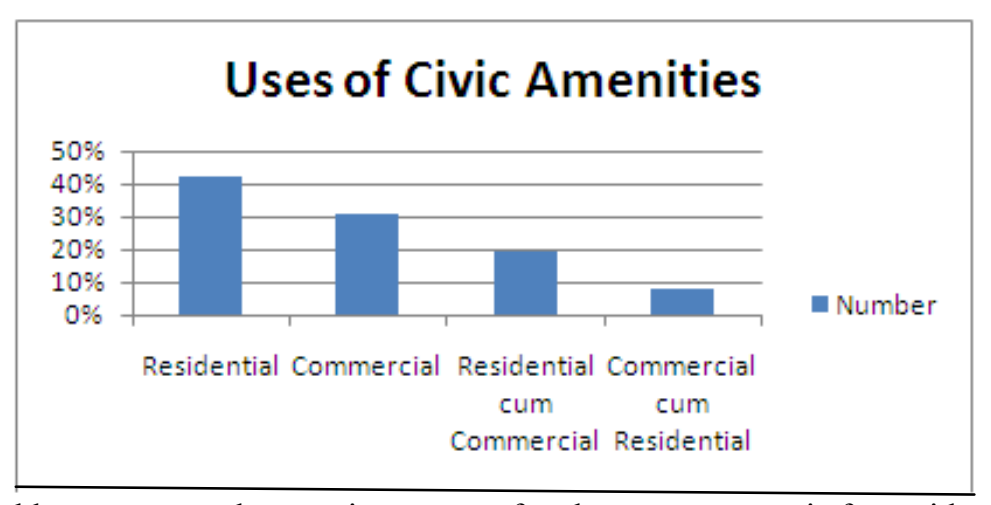

Above the table we can see that maximum use of real estate property is for residential purpose which is 42 percent than commercial 31 percent. Beside that residential cum commercial \& commercial cum residential are 19 percent and 8 percent respectively.

At present, real estate sector of Bangladesh is a leading growth sector and is providing remarkable contributions to the GDP in Bangladesh and creating employment opportunities for the unemployed people of Bangladesh. It can be shown by the following table.

Table-2 Contribution of real estate sector of Bangladesh to the GDP (in Million TK)

\section{Source: National income section, BBS}

\begin{tabular}{|c|c|c|c|c|c|}
\hline Year & $\begin{array}{c}\text { (2008- } \\
\text { 2009) }\end{array}$ & $\begin{array}{c}\mathbf{( 2 0 0 9 -} \\
\mathbf{2 0 1 0}\end{array}$ & $\begin{array}{c}\mathbf{( 2 0 1 0 -} \\
\mathbf{2 0 1 1}\end{array}$ & $\begin{array}{c}\mathbf{( 2 0 1 1 -} \\
\mathbf{2 0 1 2}\end{array}$ & $\begin{array}{c}\mathbf{( 2 0 1 2 -} \\
\mathbf{2 0 1 3})\end{array}$ \\
\hline $\begin{array}{c}\text { Real estate renting \& } \\
\text { business service }\end{array}$ & 486,241 & 534,769 & 589,709 & 684,081 & 778,281 \\
\hline $\begin{array}{c}\text { Growth rate of real } \\
\text { estate sector }\end{array}$ & $3.69 \%$ & $9.98 \%$ & $10.27 \%$ & $16.00 \%$ & $13.777 \%$ \\
\hline
\end{tabular}

From the above Table-2, we can see that the real estate sector has provided to the GDP of Bangladesh in 2008-09 is TK. 486 million, 2009-10 is TK. 534 million, 2010-11 is TK. 589 million, 2011-12 is TK. 684 million, and 2012-13 is TK. 778 million respectively. This information indicates that the contribution of real estate sector to the GDP of Bangladesh is indispensable. So, the government of Bangladesh should take necessary steps to motivate the real estate investors/ developers to come in this sector for the development of overall economy of the country.

The housing situation in Bangladesh has never been satisfactory. The majority of dwelling units are temporary, sub-standard, unsafe and overcrowded. In all metropolitan cities of Bangladesh, there is acute shortage of housing supply and the backlog is continually increasing. Inadequate supply of dwelling units for middle and low-income people and high rental value are among the most severe challenges affecting urban living in Dhaka and other metropolitan cities in Bangladesh. At present in our country the annual required shelter varies from 3 lakh to 5.5 lakh units. At present there will need to construct approximately 4 million new houses annually to meet the future demand of people in Bangladesh.

Table-3 Living structure in Bangladesh 


\begin{tabular}{|c|c|c|}
\hline Particulars & Urban & Rural \\
\hline Average floor space per living structure & 299 square feet & 243 square feet \\
\hline Bedroom space per person & 62 square feet & 54 square feet \\
\hline Residential house of the permanent type & $22 \%$ & $1 \%$ \\
\hline Residential house of the semi-permanent type & $24 \%$ & $15 \%$ \\
\hline Residential house of the temporary type & $54 \%$ & $84 \%$ \\
\hline
\end{tabular}

Source: Sheltech Service, 2013.

From the above statistics, it is clear that land is very scarce in Bangladesh. The areas occupied by human shelters and supportive infrastructures are quite high. With the continued growth of population, land for agriculture and forest will shrink in tandem. This calls for high density settlement either in high rises or in small unit low rise apartments.

\subsection{Apartment/Real Estate development in Dhaka city}

Three decades back the city dwellers were reluctant to live in flats while ten years back some one would have thought twice before buying an apartment/flat. But in the last couple of years people have shown an increased interest in owning apartments. As mentioned earlier the main reason is economic due to increased land cost as well as construction cost. There are also other reasons such as reluctance of individuals to spend time and energy in house construction, increased awareness of apartment living, and western influence. As a result apartment-owning is becoming increasingly popular. Moreover the absentee i.e. the wage earners in Middle East and other countries are also a major contributing factor towards the increasing demand for apartments. As a result of increased demand, many apartment builders have appeared in the market in recent years. Twenty years ago there were fewer than five companies in Bangladesh engaged in developing apartments while today there are more than 600 developers. It may be mentioned here that in 1988 there were less than 20 such developers in Dhaka. At present there are 600 such developers working in Dhaka city who are members of REHAB. But there are many other companies/individuals engaged in such development in smaller scale and selling apartments to friends and relatives only. Real estate companies are now constructing apartment buildings on joint venture basis with the land owner and selling its portion of apartments to the buyers because land value and the high cost of construction, the apartments which they are selling, often goes beyond the affordability of low and middle income people. The following table-4 will give a picture of location wise per square feet land value and per square feet apartment selling price in prime locations of Dhaka city.

Table-4 Location wise Land value \& Average selling price of Apartment in 2013 in some prime location in Dhaka city

\begin{tabular}{|ccc|}
\hline Location & Land value (Tk/sft) & Selling price (Tk/sft) \\
\hline Dhanmondi & $3000-3500$ & $6000-6500$ \\
Gulshan & $3500-4000$ & $7000-8000$ \\
Baridhara & 6000 & $10000-12000$ \\
Uttara & 3000 & $5000-6000$ \\
Siddeswari & 3000 & $5000-6000$ \\
Shemoli & 2000 & 4000 \\
Mohammadpur & 2000 & 4000 \\
Green road & 2500 & $4500-5000$ \\
Elephant road & $2500-3000$ & $4500-5500$ \\
Lalmatia & 3000 & 5500 \\
Shantinagar & 2500 & $4500-5000$ \\
Niketon & 3000 & 6000 \\
Banani & $3500-4000$ & $7000-8000$ \\
Shagunbagicha & $2200-2500$ & $4500-5000$ \\
Mogbazar & $2000-2500$ & $4000-4500$ \\
Mirpur & 2500 & $3500-4000$ \\
\hline
\end{tabular}

Source: Field survey (Sheltech Development Ltd.2013)

From the recent market survey, it has been observed that the market price of lands and selling prices of apartment houses increased by 20 percent to 25 percent compared to price of year 2013 shown as above.

\subsection{Current state of High-rise building in Bangladesh}

The history of tall building in Bangladesh is only four decades old. Broadly speaking two types of high-rise buildings are constructed in terms of use type:

- Institutional buildings including government \& commercial office buildings hotels etc.

- Residential buildings particularly for middle and high income groups. 
The trend that started in 1963 with the construction of 11-storied WAPDA building at Motijheel, the Central Business District (CBD) of the capital city Dhaka has currently gained a tremendous momentum. Although tall buildings are being constructed in few numbers in other cities of the country, almost all the existing and under-construction tall buildings of the country are located in the capital city. In Dhaka, there are about 120 such notable buildings clustered mainly at the Motijheel commercial area and in places like Eskaton, Mohakhali and Banani. If one compares the number of tall buildings in the capital city with the size of the greater Dhaka with a present population of about 12 million, the insignificant proportion of the tall buildings with respect to the overall scenario becomes evident. It is evident from the steady increase in the number of tall structures has taken place in the recent years. Whereas in the sixties and seventies, on $\mathrm{n}$ verge five high rise buildings were constructed in Dhaka City, in the eighties about twenty tall buildings were constructed. Construction of tall structures attained its peak in the nineties, and, in the last five years about 50 percent of the total present number of all tall buildings of the capital city has been constructed. The trend of going high is still there.

\subsection{Development of High-rise Buildings}

High-rise buildings probably were first constructed in response to the corporate need for increased direct communication and expansion of business operation. Businessmen understood the need for proximity and personal communications and quickly recognized the value of "going vertically up" within a compact business core in the central city. This philosophy has remained, all over the world, despite the extraordinary technical advances made over the last 50 years in both transportation and telecommunications. The corporate world is not the only beneficiary of high-rise development; often other enterprises that serve corporate business or its employees also locate themselves in high-rise structures. Offices for lawyers, accountants and other business related professionals are established in close proximity to the corporations, often being located in the same building. Medical and dental practices open where they can capture and serve office workers as well as the general urban population from a central location. Even where the structure bears a corporate name and was built specifically for a corporate tenant finally ends up catering to various professional and business clients. Today's high-rise building usually contains a variety of tenants. The city itself benefits from the concentration of business space and business activity that high-rise development generates. Land values are greater in the down town areas of cities and at other prime locations that are highly attractive. In most cities, high-rises have evolved in concentrations, and those concentrations generate the highest tax returns to local government. For example in Chicago, approximately one-third of the city's real estate tax return comes from the greater downtown area covering less than $7 \%$ of the total area of the city. Depending on overall factors, during the last three decades, Dhaka City attempted to expand vertically to meet the problems of urban population explosion, scarcity of land and spiraling land price. High-rise structure also has a positive influence on city form and organization.

The tallest building in Dhaka (30 stories) has been constructed at Motijheel for office purpose. Highrise buildings for residential purposes are being seriously considered to provide an answer to urban housing problems. How far this is tenable in context of conditions prevailing in developing countries must be studied in greater depth so that planned growth in high-rise housing construction can be promoted. Because of the great size and height the development of tall buildings usually involves active interaction of public and private decision-makers. Successful public private collaboration usually revitalizes the urban environment. Thus tall building development in the form of office towers, hotels and residential apartment buildings can become a critical part of revitalization in major cities of the world, including Dhaka. In terms of Dhaka it can be seen from the map that the location of the majority of the high-rise structures are clustered in the business districts and central city areas where land value is highest.

\subsection{Prospects of High-rise Building:}

It is almost inevitable that high rise construction will increase in future in Bangladesh. In fact, in a fast growing metropolis like Dhaka where, land is scarce and land value is high, there is no other obvious option but to go for tall structures. In a country where expatriate consultants and contractors are being inducted in almost every field of technological activity, it is interesting to note that all the tall buildings in Bangladesh have been planned, designed and constructed by local architects and engineers. But high rise buildings, both commercial and residential; of Bangladesh have already revealed their merits and demerits in the very short time that they have been serving the community.

\subsection{Some of the advantages of tall buildings are given below:}

- It increases land-use density leading to proper utilization of inner city land.

- If properly designed and constructed it can increase the user efficiency for both commercial and, residential.

- It can bring positive effect on city form. 
- High-rise buildings and the users that occupy them usually return more revenue (benefits) to local governments than they require in services (costs) from them. This positive cost-benefit ratio is often used as a measure of the attractiveness of a development.

- High-rise buildings have established an efficient setting for corporate business enterprise, a significant source of revenue for local government, and a business focus for the entire metropolitan area.

- Residential uses in high-rise have resulted in both success and failure. Tall apartment buildings have successfully fulfilled the needs of upper income and middle income families in, different developing countries.

\subsection{Problems of High-Rise Building}

However, in the absence of proper urban planning and design, high rise buildings of Bangladesh are responsible, in many instances, for several problems leading to disadvantages for Dhaka and other city dwellers of Bangladesh.

Some of the disadvantages that the existing tall buildings have demonstrated due to ill planning are listed below:

- Unplanned tall structure destroys the harmony in skyline.

- It put pressures on utility services like water supply, gas and electricity.

- It increases traffic congestion and parking problem.

- It creates problems of light and ventilation for adjacent small structure.

- Fire fighting problem in the building.

- Problem related to inadequate number of lifts.

- Problems due to inadequate parking space.

- Lack of community space.

Besides, Bangladesh is recognized as an earthquake prone country by Bangladesh National Building Code (BNBC, 1993). Seven major earthquakes, magnitude equal to or more than 7.0 on the Richter scale, had affected today's Bangladesh during the last 150 years. But housings in Bangladesh seem to be constructed to meet the social demand, not as an earthquake resistant frame building.

\section{Recommendations}

The construction in Dhaka has multi-faceted roles for sustainable development. It provides the direct means for physical development, expansion, improvement and preservation through maintenance. It is the key sector in city's development. It provides the direct means for physical expansion, development and improvement. The planning and design component of construction is very vital and it contributes to high productivity. Appropriate planning and design for construction, use of modern equipment, efficient use of building materials, participation of construction actors and effective management are considered important factors for construction industry's development.

Considering all issues, following broad general recommendations both in the public and private sector should be taken into consideration:

a) Appropriate planning and programming for the construction project would be framed based on the nature of works.

b) The authority with help of professionals should formulate general guidelines of building designs. Special attention would be given to prepare appropriate planning rules, building codes etc. based on the character of the area. It will also cover building regulations and related detailing of the building and also cover selection of materials.

c) It has been observed that the construction material and equipment differ from place to place, considering this fact, specialized standards and code should be made.

d) Simple and innovative technologies should be introduced in the construction sector for high productivity. The attention should be given on its acceptability to the construction actors. Affordability to the government as well public enterprises should be taken into consideration.

e) Research and innovation for development should be encouraged. Proper research support and financial support should be provided both in public and private sectors. Even groups of entrepreneurs and individuals should be encouraged by the policies

f) Selection of building materials, the consultants are required in conjunction with experienced contractors.

g) Local based building materials as well as cheaper alternative/substitutes should be encouraged. 
h) Overall management effectiveness is essential for the construction sector. It should be managed on an institutional basis, and the construction actors have contractors, laborers, managers and other related actors as active participants.

i) Adequate legislative support is needed to recognize the construction sector as an important for national development.

j) Special attention would be given to protect the physical environment of the project's site. Existing "Legal action" procedures would be updated in which legal action can be taken against the faulty actors.

\section{Conclusion}

The planning and design approach is very important components in the Real Estate sector specially to ensure sustainability. The technology and innovation in the construction industry may reduce construction cost and time, as well as increase safety. New technological innovations, often in conjunction with materials and equipment, should be introduced into several of the disciplines within the construction industry. Such technology also ensures higher productivity, which can bring socio-economic prosperity to the country. The Government sets regulations on construction industry (building code, land use, tendering constructor's negotiation and environmental regulation) in national and local level. Changes are also sought to improve quality, management efficiency, material flow, and maintain schedules by better organization and controlling of design and production process. Without farther delay there should be mega master plan to expand the city both in horizontally and vertically with the proper and smart communications infrastructures through upholding code of conducts and maintaining international standard always, all ways within a standard time frame. Not only in Dhaka City but also in the other cities there should be same level of actions. Government's responsibility is to check whether buyers are getting everything right and has to work hand in hand with real estate companies and to sort out all problems of all parties. People expect government and private real estate sector will take the nation to the highway of Bangladeshi Dream of having a permanent house for all, class independently, may be a flat or a plot at the cost of their lifetime savings. Fix it, according to their ability, have the real spirit.

\section{References}

[1]. Annual Report (2007), National Housing Finance and Investment Ltd.

[2]. Bangladesh Bureau of Statistics, 2013.

[3]. BBS, 2003 Population Census 2001: National Report (Provisional), Dhaka: Bangladesh Bureau of Statistics.

[4]. Benjamin, D. John (2003), "The Environment and Performance of Real Estate", Journal of Real Estate Literature, Vol. No. 11, Page 279 to 324.

[5]. Field Survey, Sheltech Developer Ltd., 2012.

[6]. Hoek-Smit, Marja C. (1998). Housing Finance in Bangladesh - Improving Access to Housing Finance by Middle and Lower Income Groups, Prepared for Ministry of Local Government, Rural Development and Co-Operatives, GOB and UNDP/UNCHS (Habitat), http://housingfinance. wharton.upenn.edu/Docs/bareport.pdf.

[7]. Hossain, Mohammad, (2001), "Real Estate Marketing in Bangladesh", Journal of Marketing, London Metropolitan University, Vol. 15, No. 2, Pp.15-105.

[8]. Malpezzi, Stephen, 2000“The role of Speculation in Real Estate Cycles”, Journal of Real Estate Literature, Vol. No. 13, Page 141 to 164.

[9]. McGraw-Hill Book -Real Estate Finance (Jeffery fisher, 2000)

[10]. Michael. S J (1999), “Diversification Issues in Real Estate Investment”, Journal of Real Estate Literature, Vol. No. 07, Page 163 to 179 .

[11]. Rahman, M. M. (2005), Role of the NGOs in Urban Housing for the Poor in Dhaka, Bangladesh, GBER Vol. 5, No. 1, pp 28.

[12]. REHAB (2014) Available at: http://www.rehabhousing.com/about rehab.asp

[13]. REHAB Directory 2014, REHAB Secretariat.

[14]. Retrieved from sheltech web site: // www.sheltechdeveloper.com

[15]. Retrieved from world wide web: h t t p: // www.realestatebusiness.com

[16]. Seraj, Md. Islam, (2003), "The Real Estate Financing in Bangladesh", Journal of Marketing, Melbourne University, Vol.20, No.3, pp.50-85.

[17]. The Daily Ittefaq, May, 2013

[18]. The Daily Star, November, 2012

[19]. David L C., and Archer, Wayne, R., (2005), "Real Estate Principles: A Value Approach", McGraw-Hill Book Company, Boston, USA, Pp. 75-81.

[20]. Nadler, Michael (2006), Evaluating Private Housing Finance System, Paper presented at ENHR Conference 2006 Ljubljana, http://enhr 2006- Ljubljana. Uirs.si/publish/W02_nadler.pdf, date retrieved on November 5, 2006.

[21]. Nordberg, Rainer (2000).Alleviating Poverty through Housing Development, United Center for Human Settlements (Habitat)

[22]. http://www.unchs.org/unchs/english/hdv6n4/alleviating poverty.htm.date received on October 1, 2006 